\title{
Physiological changes in leaves of some mango cultivars as response to exposure to low temperature degrees
}

\begin{abstract}
This study was conducted throughout 2012 and 2013 seasons on leaves of Alphonso, Balady, Bullock's Heart, Helmand, Hindy Besennara, Mabrouka, Mestekawy, Nabeeh, Ewais, Spates, Taimour and Zebda mango cultivars to evaluate their ability of mango cultivars to acquire cold injury during exposure to low temperature (storage of mango leaves at $5^{\circ} \mathrm{C}$ and $10^{\circ} \mathrm{C}$ ). The changes in relative water content (RWC), membrane stability index (MSI), electrolytes leakage (EC\%) and total free amino acids in relation to exposure to low temperature degrees were studied. The RWC, MSI and TFAA were decreased by reducing temperature degree from $10^{\circ} \mathrm{C}$ to $5^{\circ} \mathrm{C}$. On contrast, $\mathrm{EC} \%$ was increased. On the other hand, as the period of exposure to low temperature lengthened the values of RWC and MSI were decreased. On contrast, EC\% and TFAA were increased. This was true when leaves exposed to $5^{\circ} \mathrm{C}$ or $10^{\circ} \mathrm{C}$ between the five periods of exposure $(2,4,6,8$ or 10 days). It is clear that exposed leaves for 10 days had more effective in decreasing RWC, MSI and TFAA than other days of exposure. On the other side, the effect of low temperature exposure was significantly differed from cultivar to another under the temperature of $5^{\circ} \mathrm{C}$ and $10^{\circ} \mathrm{C}$.
\end{abstract}

Keywords: Mango (Mangifera indica L.), cultivars, cold tolerance, biochemical changes.
Volume 3 Issue $6-2019$

Farouk M Gadallah,' Mohamed A Seif ElYazal,' Gamal A Abdel-Samad, ${ }^{2}$ Ali A Sayed'

'Botany Department, Faculty of Agriculture, Fayoum University, Fayoum 635।4, Egypt

${ }^{2}$ Horticulture Department, Faculty of Agriculture, Fayoum

University, Fayoum 63514, Egypt

Correspondence: Mohamed A Seif El-Yazal, Botany Department, Faculty of Agriculture, Fayoum University, Fayoum 635।4,Egypt, Email mas04@fayaum.edu.eg

Received: October 17, 2019 | Published: November 15, 2019

\section{Introduction}

Mango (Mangifera indica L.) is a popular, nutrional tropical fruit, which is now one of the most important fruit crops (as evergreen trees) in tropical and subtropical areas of the world. ${ }^{1}$ Mango occupies third place in total world production of major tropical fruit crops after citrus and banana. ${ }^{2}$ Environmental conditions outside the traditional areas for optimum growth of mango may impose stresses, which can result in physiological changes, reduced growth, or even permanent damage to the trees. ${ }^{3,4}$

Low temperature is acknowledged to be one of the most dominant environmental stresses that affect the growth, productivity and geographical distribution of crops and horticultural plants. ${ }^{5}$ Exposure to low, nonfreezing temperatures induces genetic, morphological, metabolic and physiological changes in plants, which result in the development of cold hardiness and acquisition of freezing tolerance. ${ }^{6}$ Mango grows over a wide range of the frost-free climates. The trees produce best in climates that have a well-defined, relatively cool dry season with high heat accumulation during flowering and fruit development period. ${ }^{7}$ A mango needs an optimum temperature range of $24-26.7^{\circ} \mathrm{C}$ and minimum threshold temperature is $10-12^{\circ} \mathrm{C}$ below this temperature, a plant shows chilling injury. ${ }^{8}$ Mango trees show high susceptibility to low temperature $\left(0-15^{\circ} \mathrm{C}\right)$. Young trees are damaged by low temperature variability among cultivars is apparent after a cold spell, but precise information on this subject is non-existent, ${ }^{9}$ nor is it known if mangoes can acclimate to cold. ${ }^{10}$ An understanding of the biology of low temperature in mango may provide the basis for potential cold-protection strategies and developing cold tolerant cultivars and may also trigger interest in the responses of other tropical and subtropical plants to cold stress. ${ }^{11}$

\section{Materials and methods}

Two experiments were conducted during 2012 and 2013, one of them carried out in a private orchard, Sayleen village, Sennouris district, Fayoum Governorate, Egypt, located at $29^{\circ} n^{\circ}$. The other one was done in the laboratory of Agricultural Botany Dept., Faculty of Agric., Fayoum University, Egypt. The experiments assess to evaluate the cold tolerance of some mango cultivars grown under Fayoum Governorate condition and check some putative physiological and biochemical events that occur following cold exposure.

\section{Climate of experiment site}

At the site of experiment, temperatures fluctuated during the duration of study and five years before the beginning of the study. In this respect, the mean monthly maximum temperature (TMax) ranging from about $17.7^{\circ} \mathrm{C}$ in January 2008 to about $40.2^{\circ} \mathrm{C}$ in August 2010 and the fluctuation in mean monthly minimum temperature (TMin) was ranging from about $5.7^{\circ} \mathrm{C}$ in January $2007 / 2008$ to about $25.2^{\circ} \mathrm{C}$ in August 2012. An extreme minimum temperature of $0.6^{\circ} \mathrm{C}$ was recorded in January 2008; however, there were large differences between the selected years (Table 1).

\section{Plant materials}

The plant materials comprised 12 mango cultivars which collected from their natural growing location in the period of November 2012 to March 2013. This is approximately the time at which the cold hardiness may be occurring. Mango trees were about 30 years old, planted in a clay soil at $5 \times 5 \mathrm{~m}$ apart. The cultivars were used in this study including most of the popular cultivars which grown in Fayoum Governorate. The tested cultivars were, Alphonso, Balady, Bullock's Heart, Helmand, Hindy Besennara, Mabrouka, Mestekawy, Nabeeh, Ewais, Spates, Taimour, and Zebda. In this study, two trials were conducted independently in the field and laboratory.

\section{Field trial}

Thirty-six trees of similar phenotype in the field (size, vigor...etc) 
with management prehistory were selected for this experiment (no further tests were carried out confirm genetic uniformity). All selected trees were allocated at random with each replicate. The trees were derived from seedlings; named Balady, while the others they had been grafted onto seedling rootstocks. To obtain a complete picture of mango cold tolerance status under natural conditions, measurements must be made at frequent intervals throughout the growth period.
Therefore, samples of ten mature terminal fully expanded leaves (similar development ages) were randomized taken from each tree (as a replication) at the end of each month from November to March. Leaves were collected (between 9 to $10 \mathrm{am}$ ) from one-year-old shoots of the mango cultivars and used as a plant material. All treatments were applied in a factorial randomized complete block design with three replicates (each of replicate represent of a tree).

Table I The Monthly mean of maximum and minimum temperatures (open air-temperature) during the period from January 2006 to March 2013

\begin{tabular}{|c|c|c|c|c|c|c|c|c|c|}
\hline Month Year & Temp. & 2006 & 2007 & 2008 & 2009 & 2010 & 2011 & 2012 & 2013 \\
\hline \multirow[t]{2}{*}{ January } & Max. & 19.4 & 19.4 & 17.7 & 20.7 & 21.9 & 20.7 & 20.4 & 23.0 \\
\hline & Min. & 6.6 & 5.7 & 5.7 & 6.7 & 7.6 & 8.0 & 7.2 & 10.3 \\
\hline \multirow[t]{2}{*}{ February } & Max. & 22.2 & 21.4 & 20.0 & 22.3 & 24.4 & 22.0 & 22.4 & 24.3 \\
\hline & Min. & 8.4 & 7.8 & 6.5 & 6.4 & 8.2 & 9.4 & 8.2 & 10.4 \\
\hline \multirow[t]{2}{*}{ March } & Max. & 26.3 & 25.0 & 28.6 & 23.2 & 27.5 & 25.6 & 25.4 & 29.0 \\
\hline & Min. & 9.7 & 9.8 & 11.6 & 7.9 & 11.4 & 9.5 & 11.8 & 12.6 \\
\hline \multirow[t]{2}{*}{ April } & Max. & 30.4 & 28.6 & 31.6 & 30.8 & 31.8 & 28.5 & 29.1 & \\
\hline & Min. & 13.3 & 12.5 & 13.7 & 12.5 & 14.3 & 13.7 & 13.6 & \\
\hline \multirow[t]{2}{*}{ May } & Max. & 33.4 & 35.2 & 35.4 & 32.8 & 34.1 & 32.8 & 34.1 & \\
\hline & Min. & 16.9 & 17.7 & 18.2 & 16.7 & 16.7 & 17.4 & 18.3 & \\
\hline \multirow[t]{2}{*}{ June } & Max. & 36.5 & 39.3 & 39.4 & 38.2 & 38.4 & 35.7 & 38.4 & \\
\hline & Min. & 20.0 & 20.7 & 22.0 & 20.4 & 21.4 & 20.6 & 21.8 & \\
\hline \multirow[t]{2}{*}{ July } & Max. & 37.4 & 38.9 & 37.7 & 38.5 & 36.3 & 38.7 & 39.8 & \\
\hline & Min. & 21.3 & 21.8 & 22.1 & 22.7 & 22.4 & 21.5 & 23.6 & \\
\hline \multirow[t]{2}{*}{ August } & Max. & 38.3 & 37.8 & 38.6 & 37.0 & 40.2 & 38.6 & 38.0 & \\
\hline & Min. & 22.1 & 21.7 & 22.2 & 21.8 & 24.5 & 22.9 & 25.2 & \\
\hline \multirow[t]{2}{*}{ September } & Max. & 34.8 & 34.3 & 35.9 & 35.2 & 36.2 & 36.1 & 35.2 & \\
\hline & Min. & 20.3 & 20.5 & 20.0 & 20.7 & 21.9 & 22.1 & 23.4 & \\
\hline \multirow[t]{2}{*}{ October } & Max. & 31.0 & 32.1 & 31.5 & 31.7 & 35.9 & 30.2 & 34.4 & \\
\hline & Min. & 17.2 & 18.3 & 17.2 & 18.1 & 21.3 & 17.7 & 22.2 & \\
\hline \multirow[t]{2}{*}{ November } & Max. & 23.6 & 26.7 & 26.6 & 25.0 & 31.3 & 26.5 & 27.9 & \\
\hline & Min. & II.I & 12.8 & 13.1 & 11.7 & 16.5 & 12.6 & 16.4 & \\
\hline \multirow[t]{2}{*}{ December } & Max. & 19.9 & 21.3 & 22.2 & 22.4 & 24.1 & 22.0 & 21.8 & \\
\hline & Min. & 7.5 & 8.2 & 9.1 & 8.9 & 10.3 & 9.7 & 11.0 & \\
\hline
\end{tabular}

*Data applied by Bureau of Meteorology, Agriculture Administration, Fayoum Governorate, Egypt

\section{Laboratory trial (cold storage)}

Studying cold tolerance in the field is difficult. Field sites often exhibit either complete survival or complete winter kill. Because of this variability, the laboratory procedures to measure cold tolerance have been developed by a number of investigators. ${ }^{12-14}$ The results have usually been in a good agreement with field observations of natural cold injury. ${ }^{15}$ At the end of November, the mature fully expanded leaves of each cultivar were collected, cleaned, washed and toweled dry then putted in a vinyl plastic bags and subjected to various low temperature treatments. In this respect, the collected leaves from each cultivar were divided in two batches; each one was composed of 1800 leaves (10 leaves in three replicates for a storage period per cultivar). These batches were stored in a refrigerator at $5^{\circ} \mathrm{C}$ and $10^{\circ} \mathrm{C}$ in darkness. Ten leaves were taken from each batch (three replicates) per cultivar every 2 days up to 10 days. The leaves not subjected to storage of low temperature were used as a control sample (zero time). Samples from these leaves were selected for physiological and biochemical studies. All treatments of cold storage were applied in a split-split plot design with three replicates (each of replicate represent of a tree).

\section{Physiological studies}

Some reliable assays to assess physiological changes related to cold tolerance of mango cultivars were done. 


\section{Relative water content (RWC, \%) estimation}

Leaf relative water content $(\%)$ was determined ${ }^{16}$ using the entire fully expanded leaves of similar age. Ten leaf samples were taken from each tree (at $8 \mathrm{am})$ to estimate RWC. Fresh weight (FW), saturated fresh weight (TW), and dry weight (DW) of leaves were determined for each cultivar. After measuring FW of freshly leaves, they were placed into containers (slightly longer than the sample) with distilled water for $24 \mathrm{~h}$ until a constant weight (TW), (the adhering water of the leaves was bottled with absorbent paper toweling). FW was measured for each sample. DW was obtained after drying these leaves at $70^{\circ} \mathrm{C}$ in an oven for $72 \mathrm{~h}$ to a constant weight. RWC (\%) was calculated as follows: $\mathbf{R W C}(\%)=(\mathrm{FW}-\mathrm{DW}) /(\mathrm{TW}-\mathrm{DW}) \times 100$.

\section{Membrane stability index (MSI, \%) estimation}

A fresh sample of $0.4 \mathrm{~g}$ (leaf segments) was collected from each cultivar to estimate. Samples were washed three times with distilled water to remove the surface-adhered electrolytes. Plant segments were divided equally and placed in two closed vials containing 20 $\mathrm{ml}$ of distilled water. One vial was incubated at $40^{\circ} \mathrm{C}$ on a water bath for $30 \mathrm{~min}$. The electrical conductivity of the solution (EC1) was determined with conductivity meter (Mod: HI99300). The second vial was boiled placed at $100^{\circ} \mathrm{C}$ for $10 \mathrm{~min}$. and electrical conductivity of the solution (EC2) was determined with conductivity meter. ${ }^{17}$ The MSI was calculated using the following formula:

$$
\operatorname{MSI}(\%)=1-(E C 1 / E C 2) \times 100
$$

\section{Electrolytes leakage (\%) estimation}

The total leakage of inorganic ions was estimated ${ }^{17}$ using leaf samples that were cut into equal sized pieces ( $1 \mathrm{~g} /$ replicate). Each sample was placed in boiling glass bottle (100 ml brown glass bottle) containing $50 \mathrm{ml}$ deionized water. Bottles were then incubated at $25^{\circ} \mathrm{C}$ in an incubator for $24 \mathrm{~h}$, and then the electrical conductivity (EC1) of the solution was recorded using a conductivity meter (Mod: HI99300). The bottles were then boiled at $100^{\circ} \mathrm{C}$ for $7 \mathrm{~min}$, and reincubated at $25^{\circ} \mathrm{C}$ in an incubator for $24 \mathrm{~h}$, and then the electrical conductivity of the solution was recorded (EC2). Electrolyte leakage (EL, \%) was calculated using the following formula:

$$
E L(\%)=(E C 1 / E C 2) \times 100
$$

\section{Total free amino acids}

Total free amino acids concentration $\left(\mathrm{mgg}^{-1} \mathrm{DW}\right)$ was determined calorimetrically according to. ${ }^{18} \mathrm{~A}$ ninhydrin solution was prepared by dissolving $2 \mathrm{~g}$ ninhydrin in $25 \mathrm{ml}$ acetone, and then adding $25 \mathrm{ml} 0.2 \mathrm{M}$ acetate buffer, $\mathrm{pH}$ 5.5. The ninhydrin solution was stored in a brown bottle to protect it from light. A standard solution of arginine was prepared by dissolving $5 \mathrm{mg}$ in $10 \mathrm{ml} 0.1 \mathrm{M} \mathrm{HCl}$. Ninhydrin reagent $(1 \mathrm{ml})$ was added to $1 \mathrm{ml}$ of the amino acid solution in a test tube. Water was added to each tube to a total volume of $4 \mathrm{ml}$. After mixing well, the tube was kept in a boiling water bath for $15 \mathrm{~min}$. The contents of the tube were then cooled to room temperature and $1.0 \mathrm{ml} \mathrm{50 \%} \mathrm{(v/v)}$ ethanol was added. The pink colour that developed was measured by its absorbance at $550 \mathrm{~nm}$ using a spectrophotometer (Spectronic 20, Bausch \& Lamb). To determine the content of total free amino acids in each leaf sample (or leakage), the same steps as above were followed for a standard curve based on arginine.

\section{Results}

\section{Relative water content (RWC, \%)}

The pattern of changes in RWC of leaves stored at $5^{\circ} \mathrm{C}$ and $10^{\circ} \mathrm{C}$ are shown in Table 2 . The results indicate that RWC was significantly differed among the tested cultivars since, the cultivar of Balady gave the minimum value in RWC as compared to the others reached to the maximum value by the cultivar of Alphonso when the leaves were exposed to $5^{\circ} \mathrm{C}$ while, the exposure of leaves to the temperature of $10^{\circ} \mathrm{C}$, the cultivar of Helmand recorded the highest value of RWC (\%) and the lowest one was exhibited by the cultivar of Balady. However, when the different mango cultivars were exposed to low temperature of $5^{\circ} \mathrm{C}$ or $10^{\circ} \mathrm{C}$, no clear trend was detected between the periods of storage.

Table 2 Relative water content (\%) in leaves of some mango cultivars after exposure to low temperature degrees $\left(5^{\circ} \mathrm{C}\right.$ and $\left.10^{\circ} \mathrm{C}\right)$ at various storage periods

\begin{tabular}{|c|c|c|c|c|c|c|c|c|c|c|c|c|c|}
\hline \multirow{3}{*}{ Cultivars } & \multirow{3}{*}{ 0-time } & \multicolumn{12}{|c|}{ Temperature degrees $\left({ }^{\circ} \mathrm{C}\right)$ and storage periods (day) } \\
\hline & & \multicolumn{5}{|l|}{$5^{\circ} \mathrm{C}$} & \multirow{2}{*}{ Mean } & \multicolumn{6}{|l|}{$10^{\circ} \mathrm{C}$} \\
\hline & & 2 & 4 & 6 & 8 & 10 & & 2 & 4 & 6 & 8 & 10 & Mean \\
\hline Alphonso & 125.3 & 75.9 & 165.6 & 99.1 & 89.4 & 92.3 & 104.5 & 130.4 & 106.2 & 102.7 & 113.2 & 74.6 & 105.4 \\
\hline Balady & 232.6 & 78.5 & 65.0 & 60.0 & 57.9 & 73.6 & 67.0 & 86.3 & 66.2 & 70.4 & 97.2 & 101.0 & 84.2 \\
\hline Bullock's Heart & 118.7 & 135.7 & 134.9 & 62.7 & 95.7 & 139.2 & 113.6 & 154.3 & 162.2 & 81.6 & 43.1 & 60.9 & 100.4 \\
\hline Helmand & 124.6 & 174.1 & 152.7 & 114.5 & 115.1 & 163.1 & 143.9 & 151.8 & 204.5 & 105.6 & 112.5 & 161.7 & 147.2 \\
\hline Hindy Besennara & 107.5 & 126.1 & 95.0 & 87.3 & 70.2 & 119.9 & 99.7 & 152.2 & 148.9 & 67.9 & 74.8 & 112.2 & 111.2 \\
\hline Mabrouka & 135.4 & 132.5 & 92.4 & 76.2 & 117.2 & 154.5 & 114.6 & 179.3 & 168.0 & 55.4 & 99.7 & 94.6 & 119.4 \\
\hline Mestekawy & 140.5 & 119.0 & 94.2 & 83.6 & 130.4 & 124.8 & 110.4 & 172.6 & 137.2 & 98.2 & 69.0 & 108.9 & 117.2 \\
\hline Nabeeh & 147.0 & 150.2 & 161.9 & 117.1 & 134.3 & 179.6 & 148.6 & 165.9 & 170.6 & 83.5 & 104.0 & 105.2 & 125.9 \\
\hline Ewais & 120.7 & 124.7 & 122.3 & 112.9 & 77.8 & 153.4 & 118.2 & 156.7 & 152.7 & 82.3 & 94.2 & 148.0 & 126.8 \\
\hline Spates & 110.8 & 112.4 & 66.0 & 76.1 & 63.8 & 85.4 & 80.8 & 269.0 & 73.8 & 106.9 & 80.0 & 87.3 & 123.4 \\
\hline Taimour & 143.0 & 136.6 & 117.6 & 126.4 & 112.4 & 180.0 & 134.6 & 171.5 & 182.8 & 100.2 & 126.6 & 116.2 & 139.5 \\
\hline Zebda & |51.I & 121.4 & 116.5 & 109.7 & 89.7 & 110.1 & 109.5 & 113.6 & 136.5 & 104.7 & 114.6 & 111.7 & 116.2 \\
\hline
\end{tabular}
(2 to 10 days) 


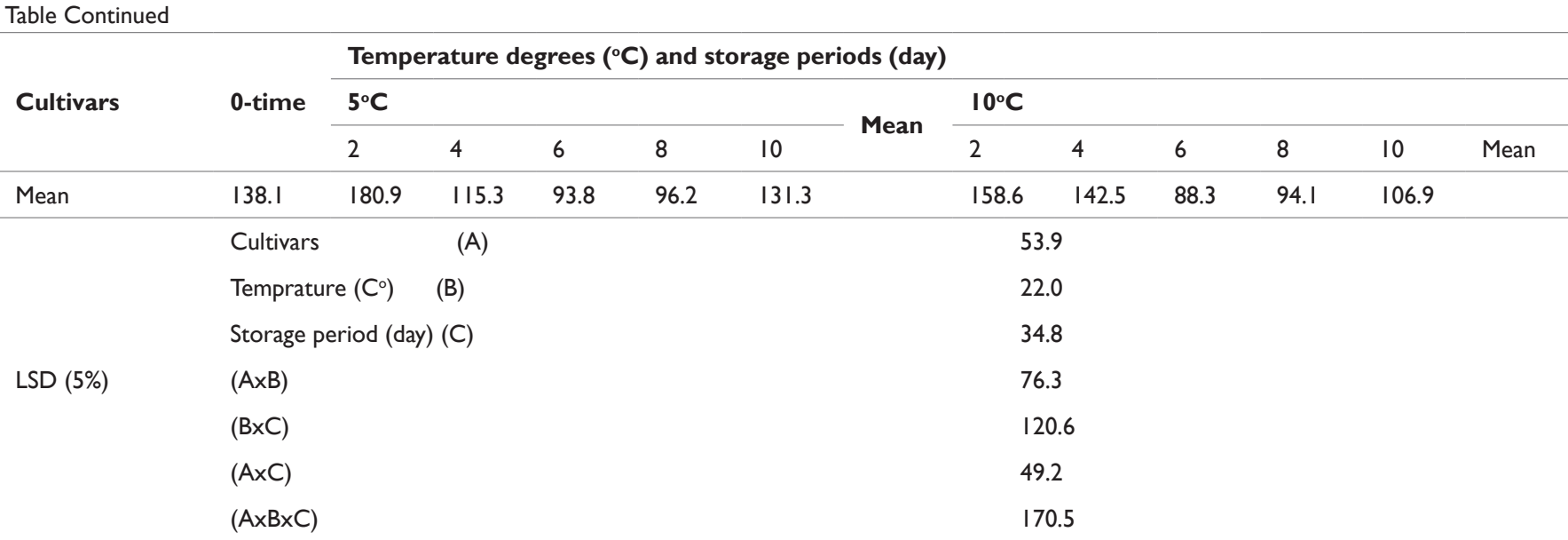

\section{Membrane stability index (MSI, \%)}

The results in Table 3 clearly explain that differences were observed during all the periods of storage for the different cultivars. However, the values of MSI were significantly differed among the tested cultivars. In this respect, it is clear that maximum MSI value was recorded by Zebda cultivar and the minimum value was observed by Spates one during the storage at $5^{\circ} \mathrm{C}$. while, at $10^{\circ} \mathrm{C}$ the highest value of MSI was obtained by Nabeeh cultivar and the lowest one was recorded by Balady one. In addition, MSI values of stored leaves was significantly influenced by the interaction effect of temperature regimes and mango cultivars but with no clear trend between the periods of storage.

Table 3 Membrane stability index (\%) in leaves of some mango cultivars after exposure to low temperature degrees $\left(5^{\circ} \mathrm{C}\right.$ and $\left.10^{\circ} \mathrm{C}\right)$ at various storage periods (2 to 10 days)

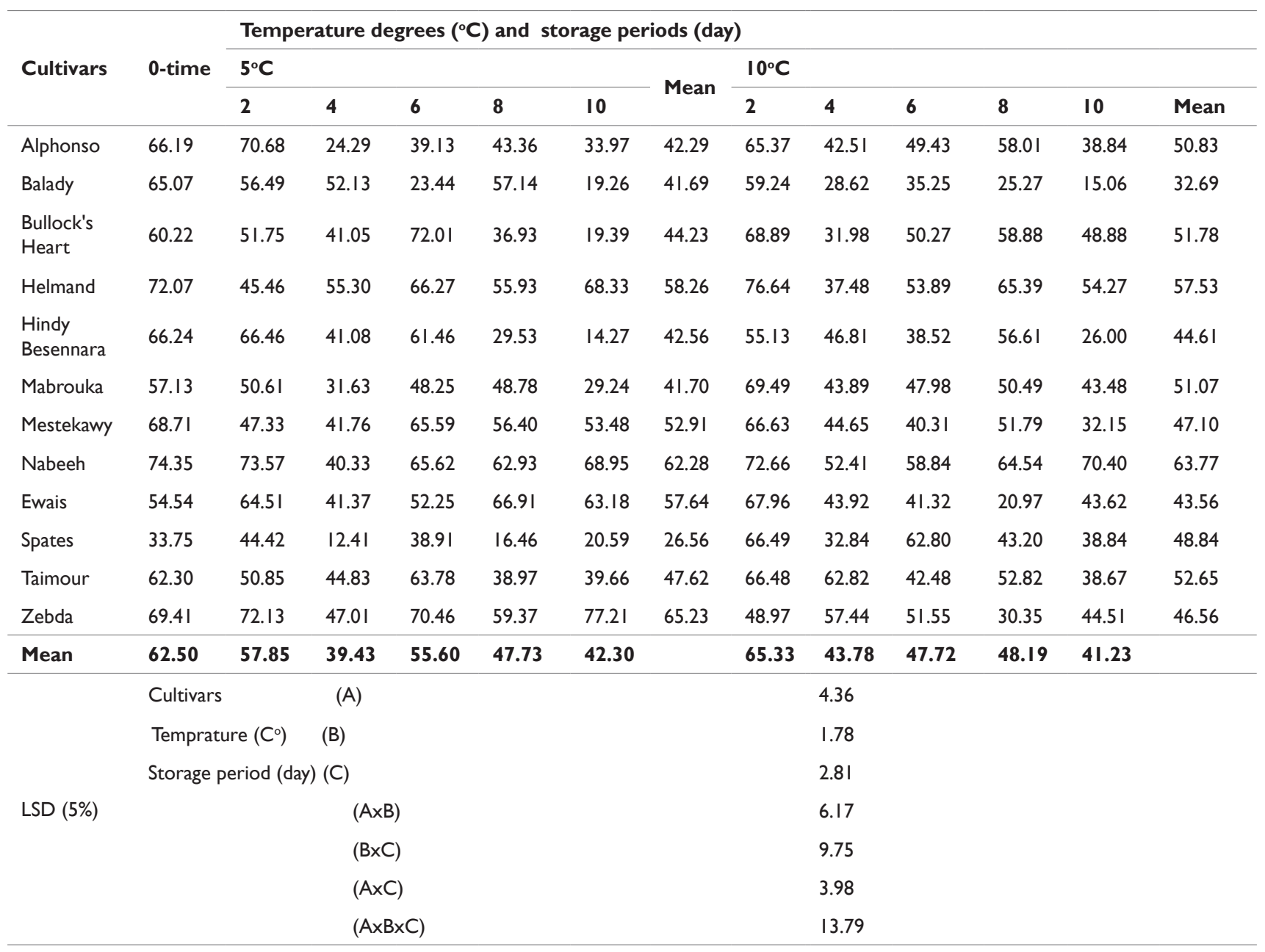




\section{Electrolytes leakage (EL, \%)}

The present results in Table 4 exhibit that an increase in EL from the leaves of the most cultivars under cold storage condition reached its maximum level by the cultivar of Mestekawy and the minimum level by the cultivar of Zebda at the temperature of $5^{\circ} \mathrm{C}$. at storage of leaves at $10^{\circ} \mathrm{C}$, EL level showed a maximum value by the cultivar of
Hindy Besennara and the minimal was recorded by Ewais cultivar. In this respect, the EL increased abruptly from $10^{\circ} \mathrm{C}$ to $5^{\circ} \mathrm{C}$ and reached a plateau at $5^{\circ} \mathrm{C}$ in the most of the tested cultivars. When different mango cultivars were exposed to low temperature either $5^{\circ} \mathrm{C}$ or $10^{\circ} \mathrm{C}$, no clear trend in EL was detected between the intervals of the cold storage for the leaves.

Table 4 Electrolytes leakage (\%) in leachate of some mango leaves after exposure to low temperature degrees $\left(5^{\circ} \mathrm{C}\right.$ and $\left.10^{\circ} \mathrm{C}\right)$ at various storage periods $(2$ to 10 days)

\begin{tabular}{|c|c|c|c|c|c|c|c|c|c|c|c|c|c|}
\hline \multirow{3}{*}{ Cultivars } & \multirow{3}{*}{ 0-time } & \multicolumn{12}{|c|}{ Temperature degrees $\left({ }^{\circ} \mathrm{C}\right)$ and storage periods (day) } \\
\hline & & \multicolumn{5}{|l|}{$5^{\circ} \mathrm{C}$} & \multirow{2}{*}{ Mean } & \multicolumn{6}{|l|}{$10^{\circ} \mathrm{C}$} \\
\hline & & 2 & 4 & 6 & 8 & 10 & & 2 & 4 & 6 & 8 & 10 & Mean \\
\hline Alphonso & 44.00 & 69.15 & 92.73 & 83.82 & 56.38 & 68.09 & 74.03 & 59.42 & 80.00 & 73.77 & 50.46 & 52.71 & 63.27 \\
\hline Balady & 49.00 & 68.45 & 90.86 & 81.17 & 56.76 & 67.13 & 72.88 & 60.30 & 81.06 & 68.09 & 74.26 & 67.08 & 70.16 \\
\hline $\begin{array}{l}\text { Bullock's } \\
\text { Heart }\end{array}$ & 82.00 & 83.52 & 75.91 & 73.45 & 66.62 & 61.69 & 72.24 & 74.82 & 75.63 & 51.65 & 47.59 & 48.57 & 59.65 \\
\hline Helmand & 46.00 & 66.32 & 49.99 & 66.06 & 44.96 & 48.86 & 55.24 & 53.63 & 65.99 & 51.78 & 44.37 & 45.24 & 52.20 \\
\hline $\begin{array}{l}\text { Hindy } \\
\text { Besennara }\end{array}$ & 47.00 & 73.09 & 90.60 & 81.34 & 49.54 & 64.00 & 71.71 & 78.29 & 75.54 & 80.30 & 61.80 & 76.81 & 74.55 \\
\hline Mabrouka & 57.00 & 75.78 & 61.78 & 77.27 & 38.65 & 47.96 & 60.29 & 89.98 & $70.5 I$ & 51.33 & 67.64 & 78.56 & 71.60 \\
\hline Mestekawy & 63.00 & 77.87 & 92.15 & 84.38 & 73.46 & 70.75 & 79.72 & 59.26 & 59.66 & 56.47 & 59.94 & 52.85 & 57.64 \\
\hline Nabeeh & 33.00 & 56.43 & 37.38 & 67.06 & 55.86 & 55.97 & 54.54 & 51.94 & 44.88 & 46.05 & 50.68 & 43.92 & 47.50 \\
\hline Ewais & 67.00 & 84.77 & 83.21 & 79.84 & 69.88 & 53.91 & 74.32 & 58.00 & 64.87 & 53.79 & 37.51 & 37.59 & 50.35 \\
\hline Spates & 74.00 & 79.65 & 83.32 & 81.68 & 54.74 & 43.43 & 68.57 & 73.91 & 65.09 & 58.33 & 50.14 & 61.02 & 61.70 \\
\hline Taimour & 47.00 & 68.45 & 68.67 & 58.64 & 56.50 & 52.32 & 60.92 & 51.52 & 75.17 & 65.07 & 55.94 & 69.14 & 63.37 \\
\hline Zebda & 50.00 & 54.41 & 50.52 & 63.44 & 51.83 & 49.81 & 54.00 & 72.54 & 68.01 & 55.15 & 61.95 & 57.31 & 62.99 \\
\hline \multirow[t]{4}{*}{ Mean } & 55.00 & 71.49 & 73.09 & 74.85 & 56.26 & & 56.99 & 65.3 & 68.87 & 59.32 & 55.19 & 57.57 & \\
\hline & \multicolumn{2}{|l|}{ Cultivars } & \multicolumn{4}{|l|}{ (A) } & & & \multicolumn{5}{|l|}{4.28} \\
\hline & \multicolumn{2}{|c|}{ Temprature $\left(\mathrm{C}^{\circ}\right)$} & \multicolumn{4}{|l|}{ (B) } & & & \multicolumn{5}{|l|}{1.75} \\
\hline & \multicolumn{6}{|c|}{ Storage period (day) (C) } & & & \multicolumn{5}{|l|}{2.76} \\
\hline \multirow[t]{4}{*}{ LSD (5\%) } & \multicolumn{6}{|c|}{$(A \times B)$} & & & \multicolumn{5}{|l|}{6.05} \\
\hline & \multicolumn{6}{|c|}{$(\mathrm{B} \times \mathrm{C})$} & & & \multicolumn{5}{|l|}{9.57} \\
\hline & \multicolumn{6}{|c|}{$(A \times C)$} & & & \multicolumn{5}{|l|}{3.91} \\
\hline & \multicolumn{6}{|c|}{$(\mathrm{A} \times \mathrm{B} \times \mathrm{C})$} & & & \multicolumn{5}{|l|}{13.54} \\
\hline
\end{tabular}

\section{Total free amino acids (TFAA)}

As it can be seen from the data in Table 5 that, in the leachates of stored leaves, there is an increase in TFAA leakage to reach a maximal level by the cultivar of Mabrouka and a minimal level was recorded by the cultivar of Mestekawy at the temperature of $5^{\circ} \mathrm{C}$. The amount of leached TFAA from stored leaves into the imbibing medium recorded the highest value by the cultivar of Bullock's Heart and the lowest was given by Hindy Besennara at the temperature of $10^{\circ} \mathrm{C}$. However, the level of leached TFAA was significantly differed among the tested cultivars. The changes in TFAA along the period of storage have not any trend between the times of storage for all the tested cultivars.

\section{Discussion}

More than half of the 350000 plant species on earth are grown in the tropics and subtropics. In the course of evolution, they could not develop the ability to withstand low temperatures. ${ }^{19}$ Most of these are damaged during storage or exposing at temperatures above the freezing point of tissue, but lower than $15^{\circ} \mathrm{C}$ (chilling temperatures). This damage is called chilling injury as opposed to damage during freezing (freezing injury). ${ }^{20}$ Thus, chilling injury is damage to chilling sensitive plant species during exposure to chilling temperatures. Chilling temperatures lead to numerous physiological disturbances in the cells of chilling-sensitive plant and result in chilling injury and death of tropical and subtropical. ${ }^{19}$ Obviously, the problem of plant resistance to chilling temperature, which often occurs in spring and autumn in many countries, is important for practical plant breeding. A change in the Egyptian climate has already been observed during the last decades, and this is expected to continue throughout this century. This change in climate affects the behavior of fruit trees and their productivity. In 2008, Egypt was exposed to a wave of frost that caused severe damage to mango trees; Hence, there is a need to know which 
cultivars are resistant to winter cold..$^{21}$ As a result of this sensitivity, low temperature produce a range of physiological and metabolic disorders that lead to serious losses. The various dysfunctions that arise under low temperature conditions result in various physical and metabolic changes that are easily scored and which can therefore be used to assess the degree of chilling injury. The effect of low temperature on RWC in mango cultivars leaves in Table 2 show that the high content of RWC in the cultivars of Mabrouka; Alphonso as well as Helmand under field and laboratory studies respectively is commonly related to the increased cold hardiness. The water status may also have an indirect effect on cold hardiness mediated by a decreased respiratory consumption of cryoprotective sugars in dehydration tissues..$^{22}$ The changes in both the amount and physical state of water are perhaps dependent on the accumulation of hydrophilic substances such as proteins and sugars. Plants may develop the capacity not only to retain water in tissues but also to protect cell structure against desiccation by accumulating substances that bind water molecules, which leads to a reduction in free water and to an increase in bond water. ${ }^{23,24}$ Additionally, lowering the temperature results in increased viscosity of water and membranes, hydraulic conductivity for water uptake may be reduced, regardless whether uptake is induced by cell water deficit. Reduced temperatures also affect cell metabolism, including photosynthesis associated to these processes. Availability of solutes is also an important of cell expansion and photosynthesis and respiration are potential sources of such solutes. Thus, temperature effects on cell metabolism may also reflects on the water uptake. So, because lowtemperature may affect water uptake associated to both changes in hydraulic conductivity and cell metabolism, measurements of RWC may vary greatly with temperature in rapidly expanding tissues, regardless the imbibition period. ${ }^{25}$ Cell membrane is the first barrier that separates cells from their environment and also is a primary target for damage under environmental stress. Dysfunction of cell membrane at low temperature is considered to be the primary molecular events ultimately leading to the development of chilling injury symptoms. ${ }^{26}$ Maintenance of membrane stability at low temperature is important for plant resistance to cold stress. ${ }^{27}$ Membrane lipids from chillresistant plants often have a great proportion of unsaturated fatty acids than those from chill-sensitive plants. ${ }^{28}$ This rising in lipids (unsaturated fatty acids) allows membranes to remain fluid by lowering the temperature at which the membrane lipids begin a gradual phase change from fluid to semicrystalline. Thus, desaturation of fatty acid provides some protection against damage from chilling. In cold tolerant plants, the modified membranes are better able to remain fluid and function at lower temperature. ${ }^{29}$ In this study, MSI is an important indicator for chilling tolerance, as was illustrated by which mango leaves under field conditions (Table 3), the cultivar of Helmand recorded the highest value of MSI and the lowest by Spates one. But, Zebda and Spates stored at $5{ }^{\circ} \mathrm{C}$ as well as Nabeeh and Balady at $10^{\circ} \mathrm{C}$ show relatively higher and lower tolerant to low temperature in terms of MSI, respectively (Table 3). Moreover, electrolytes leakage is widely used to measure chilling damage as well as to quantity species resistance to cold and chilling injury in conifer ${ }^{30}$ and in apple. ${ }^{31}$ Low temperature alters the physical properties of cell membranes. Chilling of sensitive plants leads to multiple changes in their membranes, which enhance permeable properties of cell membrane. ${ }^{19}$ These changes in the state of membranes may lead to secondary of irreversible reactions, depending on temperature, exposure duration and sensitivity of the species (or cultivars). After a prolonged chilling, these changes will cause loss of membrane integrity and comport mentation, the leakage of solutes, decrease of oxidative activity of mitochondria, increase of the activation energy of membrane-bond enzymes including $\mathrm{H}^{+-}$ATPase, reduce the rate of photosynthesis, cause disruption and imbalance of metabolism, the accumulation of toxic substances and the symptoms of chilling injury. ${ }^{32,33}$ In addition, A number of species of tropical have the lateral phase separation temperature some higher $\left(15^{\circ} \mathrm{C}\right)$ than in plants from temperate zones $\left(6-8^{\circ} \mathrm{C}\right)$ suggesting that plants reduce the freezing point of membranes with the distance from zone of tropical origin. ${ }^{34}$ However, the increased leakage of electrolytes from the cultivar of Hindy Besennara (Tables 4) and Mestekawy cultivar was interpreted as resulting from deteriorative changes in membranes and corresponds to the presence of released inorganic and organic ions. Similar results were obtained by Loay ${ }^{35}$ and Chinnusamy et al. ${ }^{36}$

Table 5 Total free amino acids concentration $\left(\mathrm{mg} \mathrm{lo0}^{-1} \mathrm{FW}\right)$ in leachate of some mango cultivars leaves after exposure to low temperature degrees $\left(5^{\circ} \mathrm{C}\right.$ and $10^{\circ} \mathrm{C}$ ) at various storage periods ( 2 to 10 days)

\section{Temperature $d$ storage periods (day)}

\begin{tabular}{|c|c|c|c|c|c|c|c|c|c|c|c|c|c|}
\hline \multirow[t]{2}{*}{ Cultivars } & \multirow[t]{2}{*}{0 -time } & \multicolumn{5}{|l|}{$5^{\circ} \mathrm{C}$} & \multirow{2}{*}{ Mean } & \multicolumn{6}{|l|}{$10^{\circ} \mathrm{C}$} \\
\hline & & 2 & 4 & 6 & 8 & 10 & & 2 & 4 & 6 & 8 & 10 & Mean \\
\hline Alphonso & 13.33 & 28.09 & 29.52 & 49.04 & 34.76 & 27.62 & 33.81 & 26.66 & 34.28 & 23.81 & 15.24 & 25.24 & 25.04 \\
\hline Balady & 19.05 & 37.14 & 17.14 & 40.95 & 26.19 & $|5.7|$ & 27.43 & 46.66 & 36.66 & 34.28 & 19.52 & 23.81 & 32.19 \\
\hline $\begin{array}{l}\text { Bullock's } \\
\text { Heart }\end{array}$ & 12.86 & 37.61 & 27.14 & 36.19 & 35.23 & 20.00 & 31.23 & 51.90 & 50.95 & 24.76 & 16.66 & 22.38 & 33.33 \\
\hline Helmand & 14.76 & 30.00 & 21.90 & 28.09 & 24.76 & 20.95 & 25.14 & 30.47 & 34.28 & 22.38 & 32.85 & 39.04 & 31.81 \\
\hline $\begin{array}{l}\text { Hindy } \\
\text { Besennara }\end{array}$ & 20.00 & 20.47 & 25.71 & 30.00 & 27.62 & 23.19 & 25.40 & 21.43 & 20.47 & 18.09 & 20.95 & 22.38 & 20.66 \\
\hline Mabrouka & $|5.7|$ & 34.28 & 32.85 & 49.04 & 31.90 & 28.57 & 35.33 & 46.66 & 29.04 & 22.85 & 17.14 & 25.24 & 28.19 \\
\hline Mestekawy & 17.62 & 25.71 & 20.00 & 20.00 & 18.57 & 18.09 & 20.47 & 31.42 & 30.95 & 21.43 & 21.90 & 21.43 & 25.43 \\
\hline Nabeeh & 16.19 & 25.24 & 26.66 & 26.19 & 17.14 & 26.66 & 24.38 & 23.33 & 15.24 & 20.95 & 28.09 & 26.66 & 22.85 \\
\hline Ewais & $|3.8|$ & 16.66 & 20.95 & 24.28 & 26.66 & 19.52 & 21.62 & 21.43 & 30.95 & 18.09 & 19.52 & 20.00 & 22.00 \\
\hline Spates & $\mid 4.28$ & 28.09 & 32.85 & 28.57 & 33.33 & 26.19 & 29.81 & 23.33 & 25.24 & 25.24 & 21.90 & 19.05 & 22.95 \\
\hline Taimour & $|3.8|$ & 35.71 & 42.38 & 33.33 & 21.90 & 29.04 & 32.47 & 43.80 & 27.14 & 19.05 & 14.28 & 18.57 & 24.57 \\
\hline
\end{tabular}


Table Continued

\section{Temperature $d$ storage periods (day)}

\begin{tabular}{|c|c|c|c|c|c|c|c|c|c|c|c|c|c|}
\hline \multirow[t]{2}{*}{ Cultivars } & \multirow[t]{2}{*}{ 0-time } & \multicolumn{5}{|l|}{$5^{\circ} \mathrm{C}$} & \multirow{2}{*}{ Mean } & \multicolumn{6}{|l|}{$10^{\circ} \mathrm{C}$} \\
\hline & & 2 & 4 & 6 & 8 & 10 & & 2 & 4 & 6 & 8 & 10 & Mean \\
\hline Zebda & 10.95 & 18.57 & 18.09 & 39.04 & 26.66 & 20.95 & 24.66 & 24.28 & 18.09 & $|5.7|$ & 19.05 & 32.85 & 22.00 \\
\hline \multirow[t]{4}{*}{ Mean } & 15.20 & 28.13 & 26.27 & 33.73 & 27.06 & 23.04 & & 32.62 & 29.44 & 22.22 & 20.59 & 24.72 & \\
\hline & \multicolumn{2}{|l|}{ Cultivars } & \multicolumn{4}{|l|}{ (A) } & & & \multicolumn{5}{|l|}{3.36} \\
\hline & \multicolumn{2}{|c|}{ Temprature $\left(\mathrm{C}^{\circ}\right)$} & (B) & & & & & & \multicolumn{5}{|l|}{1.37} \\
\hline & \multicolumn{6}{|c|}{ Storage period (day) (C) } & & & \multicolumn{5}{|l|}{2.17} \\
\hline \multirow[t]{4}{*}{ LSD (5\%) } & \multicolumn{6}{|c|}{$(A \times B)$} & & & \multicolumn{5}{|l|}{4.76} \\
\hline & \multicolumn{6}{|c|}{$(B \times C)$} & & & \multicolumn{5}{|l|}{7.52} \\
\hline & \multicolumn{6}{|c|}{$(A \times C)$} & & & \multicolumn{5}{|l|}{3.07} \\
\hline & \multicolumn{6}{|c|}{$(\mathrm{A} \times \mathrm{B} \times \mathrm{C})$} & & & \multicolumn{5}{|l|}{10.64} \\
\hline
\end{tabular}

Alternations in the level of total free amino acids TFAA content in the leaves have been shown when plants are subjected to artificial conditions (laboratory study, Table), the cultivar of Alphonso (field conditions) and Balady one (storage of at $5^{\circ} \mathrm{C}$ and $10^{\circ} \mathrm{C}$ ) recorded the highest values of TFAA. Accumulation of substantial amounts of compatible TFAA play a role in protection of cells from cold injury. ${ }^{37,38}$ In previous study, cold treated plants were shown to have relatively increased amounts of free amino acids. ${ }^{39}$

\section{Acknowledgments}

None.

\section{Conflicts of interests}

Authors declare no conflict of interest exists.

\section{References}

1. Mitra SK, Baldwin EA. Mango. In: Mitra SK. editor. Postharvest physiology and storage of tropical and subtropical fruits. CAB international. New York; 85-122.

2. Alonso G, Blaikie SJ. Seasonal variation of carbon assimilation in mango (c.v. Kensington Pride): Effect of flowering treatments. Aust J Agric Res. 2003;54:309-321.

3. Schaffer B, Whiley AW, Grane JH. Mango. In- Handbook of environmental physiology of fruit crops. Volume II. sub-tropical and tropical crops. In: Schaffer B, Anderson PC, editors. CRC Press Inc., Boca Raton, FL. USA; 1994:165-197.

4. Sharma S, Rao TVR. Responses of fresh-cut products of four mango cultivars under two different storage conditions. J Food Sci Technol. 2017;54(6):1689-1702.

5. Boyer JS. Plant productivity and environment. Science. 1982;218(4571):443-448.

6. Huner NPA, Öquist G, Hurry VM, et al. Photosynthesis, Photoinhibition and low temperature acclimation in cold tolerant plants. Photosynth Res. 1993;37(1):19-39.

7. Abd El-Moniem EA, Ismail OM, Shaban AEA. Changes in leaves component of some mango cultivars in relation to exposure to low temperature degrees. World J Agric Sci. 2010;6(2):212-217.

8. Nene YL, Shiela VK, Moss JP. Tapioca-a potential substitute for agar in tissue culture media. Curr Sci. 1996;70:493-494.
9. Farooq S, Azam F. The Co-existence of salt and drought tolerance in Triticaceae. Hereditas. 2002;135(2-3):205-210.

10. Mckellar MA, Buchanan DW, Campbell CW. Cold hardiness of two cultivars of avocado and a mango. Proc Fla State Hort. Soc. 1983;96:212-215.

11. Hao W, Arora R. Freezing tolerance and cold acclimation in guava (Psidium guajava L.). HortSci. 2009;44(5):1258-1266.

12. Rapaczb M. Cold-deacclimation of oilseed rape (Brassica napus var. oleifera) in response to fluctuating temperatures and photoperiod. Ann Bot London. 2002;89:543-549.

13. Rife CL, Zeinali H. Cold tolerance in oilseed rape over varying acclimation durations. Crop Sci. 2003;43:96-100.

14. Ghassemi-Golezani K, Khomari S, Valizadeh M, et al. Changes in chlorophyll content and fluorescence of leaves of winter rapeseed affected by seedling vigor and cold acclimation duration. J Food Agri Environ. 2008;6:196-199.

15. Pellett H, Gearhart M, Dirr M. Cold hardiness capability of woody ornamental plant taxa. J Ame Soc Hort Sci. 106:239-243.

16. Peng YW, Cai W, Arara R. Over expression of a panax ginseg tonoplast aquaporin alters salt tolerance, drought tolerance and cold acclimation ability in transgenic Arabidopsis plants. Planta. 2007;226:729-740.

17. Lutts $\mathrm{S}$, Kiner JM, Bouharmont $\mathrm{J}$. $\mathrm{NaCl}$ induced senescence in leaves of rice cultivars differing in salinity resistance. Ann Bot. 1996;78:389-398.

18. Jayarman J. Laboratory Manual in Biochemistry. Wiley Eastern Ltd., New York, NY, USA; 1981;61-73.

19. Lukatkin AS, Brazaitytė A, Bobinas C, et al. Chilling injury in chillingsensitive plants: a review. Žemdirbystè-Agriculture. 2012;99(2):111124.

20. Raison JK, Lyons JM. Chilling injury: A plea for uniform terminology. Plant Cell Environ. 1986;9(9):685-686.

21. Ismail OM. Use of electrical conductivity as a tool for determining damage index of some mango cultivars. Inter J Plant \& Soil Sci. 2014;3(5):448-456.

22. Ögren E. Premature dehardening in Vaccinium myrtillus during a mild winter: a cause for winter dieback. Functional Ecology. 1996;10:724 732

23. Guy CL. Cold acclimation and freezing stress tolerance: role of protein metabolism. Ann Rev Plant Physiol. 1990;41:187-223. 
24. Yoshida M, Abe J, Moriyama M, et al. Seasonal changes in the physica state of crown water associated with freezing tolerant in winter wheat Plant Physiol. 1997;99:363-370.

25. Yamasaki S, Dillenburg LR. Measurements of leaf relative water content in Araucaria angustifolia. Revista Brasileria de Fisiologia Vegetal. 1999;11(2):69-75

26. Parkin KL, Kuo SJ. Chilling-induced lipid degradation in cucumber (Cucumis sativa L. CV Hybrid C) fruit. Plant Physiol. 1989;90:10491056 .

27. Wongsheree T, Ketsa S, Van Doorn WG. The relationship between chilling injury and membrane damage in lemon basil (Ocimum $\times$ citriodourum) leaves. Post Biol Technol. 2009;51:91-96.

28. Palta JP, Whitaker BD, Weiss LS. Plasma membrane lipids associated with genetic variability in freezing tolerance and cold acclimation of solanum species. Plant Physiol. 1993;103:793-803.

29. Williams JP, Khan MU, Mitchell K, et al. The effect of temperature on the level and biosynthesis of unsaturated fatty acids in diacylglycerols of brassica napus leaves. Plant Physiol. 1988;87:904-910.

30. Mckay H. Electrolyte leakage from fine roots of conifer seedlings: A rapid index of plant vitality following cold storage. Can J For Res. 1992;22:1371-1377.

31. Suwapanich R, Haesungcharoen M. Application of thermal properties to predict chilling injury of mango fruits. J Agric \& Soc Sci. 2006;4(2):225226.
32. Quinn PJ. Effect of temperature on cell membranes. Symp Soc Exp Biol. Cambridge, UK. 1998;42:237-258.

33. Kasamo K, Yamaguchi M, Nakamura Y. Mechanism of the chillinginduced decrease in proton pumping across the tonoplast of rice cells. Plant and Cell Physiol. 2000;41(7):840-849.

34. Terzaghi WB, Fork DC, Berry JA, et al. Low and high temperature limits to PSII. A survey using transparinaric acid, delayed light emission and F0 chlorophyll fluorescence. Plant Physiol. 1989;91(4):1494-1500.

35. Loay A. Chilling injury in mangoes. Ph.D. Thesis. Wageningen University. 2005;1-226.

36. Chinnusamy V, Zhu J, Zhu J. Cold stress regulation of gene expression in plants. Trends in Plant Sci. 2007; 10(12):244-251.

37. Yuanyuan M, Yali Z, Jiang L, et al. Roles of plant soluble sugars and their responses to plant cold stress. Afr J Biotech. 2009;8(10):2004-2010.

38. Davey MP, Woodward FI, Quick WP. Intraspecific variation in coldtemperature metabolic phenotypes of Arabidopsis lyrata ssp. Petraea Metabolomics. 2009;5:138-149.

39. Malik, NSA, Perez JL, Kunta M. Changes in free amino acid levels in sour orange leaves in response to cold stress and during recovery from cold stress. J Food Agric \& Environ. 2013;11(1):1086-1088. 